Meta

Journal des traducteurs

Translators' Journal

\title{
The Role of Translation in the Reception of Claude Simon
}

\section{Marilyn Gaddis Rose}

Volume 34, numéro 2, juin 1989

URI : https://id.erudit.org/iderudit/003985ar

DOI : https://doi.org/10.7202/003985ar

Aller au sommaire du numéro

Éditeur(s)

Les Presses de l'Université de Montréal

ISSN

0026-0452 (imprimé)

1492-1421 (numérique)

Découvrir la revue

Citer cet article

Gaddis Rose, M. (1989). The Role of Translation in the Reception of Claude Simon. Meta, 34(2), 169-178. https://doi.org/10.7202/003985ar d'utilisation que vous pouvez consulter en ligne.

https://apropos.erudit.org/fr/usagers/politique-dutilisation/ 


\title{
THE ROLE OF TRANSLATION IN THE RECEPTION OF CLAUDE SIMON
}

\author{
MARILYN Gaddis Rose \\ University Center at Binghamton (SUNY), New York, USA
}

When the Nobel Academy awarded the 1985 prize for literature to Claude Simon (1913-), it caught North American readers, even the Francophiles, off guard. ${ }^{1}$ Even as a coterie author, he did not have a following here. Unlike other unexpected choices like Czech poet Jaroslav Seifert in 1984 or Elias Canetti in 1981 where English translations lagged behind publication, Simon's selection uncovered an extensive translation corpus. Were these translations responsible for Simon being nearly unknown to English-language readers? At first glance, he would appear to write novels which serious readers would find fascinating. After all, la Route des Flandres (1960; trans. The Flanders Road, 1961) explores a momentous historical event, the Fall of France, May-June 1940, in a mode established, even canonized, by the Nobel award to William Faulkner in 1949. Why has The Flanders Road never entered the American post-secondary general literature curriculum like Camus' The Stranger or Beckett's Waiting for Godot? Certainly controversial English translations never interfered with the reception of these works, ${ }^{2}$ and conceptually they are no more accessible. A cursory review of Simon's English translations with a detailed spot-checking of Richard Howard's The Flanders Road should both highlight a master translator's strategies and suggest by negative implication what makes a masterly work a masterpiece. To use Gumbrecht's distinction, ${ }^{3}$ while la Route des Flandres achieved canon status almost at once, ${ }^{4}$ it still seems unlikely that it will ever become a classic. In any event, our documentation will indicate that English translations cannot be faulted for Simon's English reception and suggest the subtext itself works against wide and enduring reader acceptance, at least with English-language readers.

Only two of the translations, Helen R. Lane's Triptych and Daniel Weissbort's The World Around Us were listed as being in print when the award was announced, although his chief U.S. publisher George Braziller promptly advertised that Richard Howard's translations were available. The Library of Congress lists Spanish and German translations, and Le Monde claims translations in 18 countries. I agree with Nicole Zand reporting on Assises de la traduction littéraire à Arles, November 9-12 (Le Monde) that his Swedish translator Carl-Gustav Bjurstroem can take some credit for his election. Still, given the importance of English as a lingua franca, I think his English translators Howard, Lane, Weissbort, and John Fletcher (forthcoming), far from being responsible for his poor reception, can take major credit for whatever favorable reputation Simon has with English readers. 5

Indeed, although his craftsmanship requires his translators' closest attention, it also provides considerable guidance. 6 The novels are enigmatic by design, but a translator is obviously the super-reader who can be counted on to find that design. Simon takes up the major problematics of human experience-war in its discouraging manifestations (retreat, defeat, imprisonment, terrorism, collaboration), love in its degrading manifestations (homosexual and heterosexual rape, wife and child abuse, adultery, polysex, zooerastia), human habits in their self-destructive manifestations (alcohol abuse, suicide, gluttony, greed), and human acts in their anti-social manifestations (collapse of the family from 
disrespect to incest, murder, anti-semitism, thuggery, thievery, blackmail). These horrors may be plain and plainly wrong. But when peace, charity, self-fulfillment, and constructuive good citizenship are frequently, if not inevitably, viable alternatives, the persistence of these horrors and mankind's persistence despite these horrors become enigmatic. E.g., what in Divine Design or human dynamics necessitates or encourages such devastating patterns in collective and individual history? And what is the relation between the two? There are the implicit rhetorical questions in Simon's corpus. But note that I said "implicit" and "rhetorical." Simon's style is our immediate and only clue that we are dealing with enigmas for which there is, if any answer, a glum answer. Yet, perhaps paradoxically, his style, while paramount, is not his novels' excuse for being. We must agree with his fellow novelist Tony Cartano that Simon has avoided the trap of écriture pure which engulfed many nouveaux romanciers like Robert Pinget, Alain Robbe-Grillet, and Nathalie Sarraute whose works could be accused of being exercises in narrative epistemology. ${ }^{7}$

He intentionally composes his narration with microscopic and telescopic exposition, dialogues interwoven with interior monologues and remembered dialogues, minute examinations of documentation, juxtaposed flashbacks, flashforwards, and animated historical reconstructions. On a micro level of discourse (say, sentence to sentence) he most frequently uses complete sentences, often with normal punctuation. But on a macro level of discourse (say, one paragraph to the next or the narrative as a whole), there is no reasonably secure narrative subject-predicate which consensus has established for each novel. E.g., in Faulkner's Absalom, Absalom the novel to which Simon's la Route des Flandres may profitably be compared, we can say that Quentin reconstructs for his Canadian college roommate the racial sin in his own Southern family. We can go further and state that Compson's Grand Design entailed brutalization of the Blacks and a repudiation of his own inescapable miscegenation, etc. Despite all the allusions which have allowed critics to speculate on cosmic justice, family loyalties, and regional ties (all concepts which open the spiritual vistas of the novel), Faulkner has constructed a pattern of containment for the reader. True enough, the multiperspectivity of his style is an obstacle at first reading. Although Simon has his obsessive scenes and recurring characters, it is far from certain that he would consider a containing pattern desirable, only certain points of reference which can be identified as such only when he repeats them. E.g., la Route des Flandres has in my opinion 12 motif scene sequences. I as reader can place them in chronological order; i.e., I take over the narrative responsibility assumed by Quentin Compson in Absalom, Absalom. But I am left always with the nagging doubt that I have made a subjective ordering that has omitted some significant aspect of the text, and in so doing $I$ have increased the possibility of falsifying the text by reading in my own biases. In short, I am not sure I have even identified the enigmas, much less come to terms with them.

Regardless of some minor objections that a another reader-translator would inevitably have, I contend that Simon's English translators have integrally transported his novels into English. Howard has drawn on his study of Faulkner and found Faulknerian rhythms appropriate and close. Lane has used acculturation; Weissbort, moderate calquing; Fletcher is using thoughtful restructuring. ${ }^{8}$ After a passing negative example on the risk in Lane's strategy, I shall make my case with Howard's translation of la Route des Flandres. Fletcher's translation is not completed; Weissbort's is of a lesser work. Quite possibly only la Route des Flandres substantively rewards rereading.

First the negative example from Lane. Her Triptych is equally revolting and just as complacent and sensational as the original. However, towards the end she makes a cultural substitution which undercuts the scenic accretion of all that has preceded. Although 
rabbitt-skinning, trout-fishing, cow-defecating, and human-copulating occur outside France, still as we struggle through Simon's gratuitous garbage, we have been reading a French novel and visualizing French landscapes, physiognomies, material culture, etc. Simon interjects a Brechtian visual: "GALERIES MODERNES ... LE CHIC, HOMMESFEMMES." Lane renders this as "BROADWAY DEPARTMENT STORE - THE CITY'S NEWEST ... LATEST FASHIONS — FOR MEN AND WOMEN."9 The effect of such a substitution, in my opinion, is to move the novel suddenly to the Poconos (our own rural resort area) thus negating, even falsifying most of the reader's previous points of reference.

Ideally I think Howard should have done all the English Simon. Generally speaking, it is nearly always advisable to have a single translator in language $X$ for an author of language $Y$ for purposes of general congeniality, lexical and stylistic consistency, extraliteray references, and continuity in personal communication. With Simon's corpus it would seem doubly advisable because of the cross-referencing of characters and episodes within the corpus. It is unfair to Simon to read only a single work of his, for as with Faulkner, Proust or Joyce, one must have read all his works in order to follow any of them. ${ }^{10}$ To appreciate fully, in some instances even to notice, the 12 scene sequences or filmstrips in la Route des Flandres, ${ }^{11}$ one must have read them elsewhere in the corpus. Since these sequences are recognizable in Simon from one section to the next and from one book to the next, they must be recognizable within a translation and from one translation to the next. Howard, who says he found his inspiration for le Vent from his immediately prior reading of Absalom, Absalom, 12 could have maintained more consistency among the works since he would have employed more uniform translation strategies (e.g., maintaining motif words and diction levels, replicating his stylistic conversions, etc.) What Howard does with Simon is exemplary in the best senses of the word. His translation of la Route des Flandres illustrates textual and hence inter-textual congruence at its best. He nearly produces an English-language isomorph; the differences are slight and, one might say, Derridean. Howard has achieved his eminence as a French to English literary translator because he has always produced English texts which are true to his own sense of the text in question. Mark the qualifiers well: true to his own sense of the text. This means his translations, although always coherent and tasteful, may not match archetypally ideal equivalences in every detail. But the results are always fitting additions to English-language literature. This is certainly the case with la Route des Flandres.

Let us begin with Simon and Howard at their best: with the fatigue and strain of the French cavalry retreat of May-June $1940^{13}$ :

un instant l'éblouissant reflet de soleil accroché ou plutôt condensé, comme s'il avait capté attiré à lui pour une fraction de seconde toute la lumière et la gloire, sur l'acier virginal... Seulement, vierge, il y avait belle lurette qu'elle ne l'était plus (p. 13).

for an instant the sun's dazzling reflection caught or rather condensed all the light and the glory on that virginal steel ... Only, it was a long time since she had been a virgin (p. 11).

The citation "un instant..." is internally and externally emblematic. The two terms most often used to label Simon's style - mise en abyme (any self-reflecting strategy to give depth) and bricolage (the handyman's improvised constructions and repairs) - are illustrated here. 14 We have parts of the most striking film clip; this is the scene which is the activity frozen for the Joseph Cornell box that this novel constructs. And we see here some of the phrases and objects that are Simon the bricoleur's favorite tools. Howard's translation is a subtle condensation of the original. Like de Reixach's saber, which catches the light and condenses all the concomitant glory of a family tradition in this poignant, obsessive scene, Howard's translation does not alter the semantic ground but pulls 
in and tidies up the signifiers. There are fewer words in the English, not just in this passage but in the novel as a whole - 96,720 words in the French compared to 81408 words in the English translation. 15 The links in the stream of associations have been stretched both to make the linkage more subtle and to accommodate normal English syntax. In French only the word "seulement" intervenes between "virginal" and "vierge." In French the reader goes pellmell from the phallic saber of de Reixach's supererogatory reflex to a reference to his wife whose presumed infidelity probably made him covertly suicidal. I trust that an English reader can follow the drift since Faulkner has habituated readers to such disconnected connectives. Syntactically the French is much more ambiguous. The "il" of "s'il a capte" has several possible antecedents: instant, reflet, soleil, sabre, de Reixach himself. Sabre is my guess, although it has not been mentioned for ten lines with four other masculine singular nouns (none of those just mentioned which I extrapolated from the sense of the passage) intervening. Howard has removed this ambiguity. Inasmuch as sword, sun, and de Reixach can all be covered by the same syntax: "s' il a capté ... à lui," Howard goes directly to what was caught on the sword, physically and metaphorically. It is, as we know, a reflection standing for the glorious de Reixach family as Georges' mother Sabine has mythologized it and as Georges and his fellow cavalryman Blum proceed to reconstruct, reinterpret, and, at least begin to demystify it. This subtle encapsulation typifies Howard's chief strategy and may account for the English text being shorter: a Pulitzer-Prize poet, Howard makes the English text tighter than the French. He does not add information, a point to be returned to later; nor does he truly subtract information, but he is less inclined than Simon to expand on cues.

Second, Howard's decision as to the appropriate tone appears occasionally not to coincide exactly with Simon's. He follows his own sense of the text in such cases and elevates the level of diction. In the passage justed quoted "il $y$ avait belle lurette" means "a long time," but it is less dignified. It is like "a coon's age" or "since Hector was a pup" - two obviously unsuitable translations, which whould have introduced an American resonance. Or consider when Georges' narrative consciousness recreates the aftermath of the defeat scene above (several other obsessive scenes have claimed his attention in the intervening 100 pages). A soldier who has already changed into civilian clothes screams, "Foutez le camp de là! Foutez-vous en civil! Cherchez des fringues dans une maison et planquez-vous!" (p. 110). The most literal meaning of "foutre le camp" is "decamp." So we have advice like "Get the hell out! Out of that uniform! Get civilian duds from some house and vamoose," etc.) Howard approaches rhyme and duple rhythm: "Get out of those ! Get into civilian clothes! Look for some clothes in a house and lie low !" (p. 109).

Thus, with a light touch he sanitizes the text. His lexicon is relatively nonshocking, despite the dread, horror, sordidness of what is being discussed. E.g., "maccabées" (p. 185, perhaps "stiffs" would be equivalent) become "corpses" (p. 187). Or when retreating exacerbates the animosities in de Reixach's platoon. Almost anything can trigger an argument. Here, for example, Blum and Wack start name-calling when Wack feels that Blum's disparagement of some peasants includes him:

Blum: "Et où est le mari? en balade à la ville?, et Wack se retournant d' une pièce, disant : "En balade comme toi, spèce de con: 'vec un casque sur la tête!, et Blum: "T'as oublié de $m$ 'appeller sale youpin. ne suis pas un con: je suis un youpin. Tu devrais pourtant te le rappeler, et Georges : Allons!, et Blum: "Laisse. Si tu savais comme je m'en f... (p. 65)

Admittedly there are cultural epithets difficult to carry over, perhaps "scum" for "con" and "kike" for "youpin," and Blum, if he hadn't been interrupted was surely going to say that he didn't give a damn - or worse. Howard makes the interchange slightly more courteous than the original: 


\begin{abstract}
"And where's the husband? Walking around town?" And Wack turning his whole body around to answer: "Walking around the way you are, you bastard, with a helmet on his head!" and Blum: "You forgot to call me a filthy Jew. I'm not a bastard: I'm a Jew. You should remember that," and Georges : "All right now!", and Blum : "Forget it. If you knew how much you..." (p. 66)
\end{abstract}

English, as William Weaver doyen of Italian-to-English translators has observed, seems to be unimaginative for cursing and insulting. 16 "Bastard" is Howard's basic expletive, taking care of "salaud," "con," "veinard."

When some minor losses are inescapable, Howard sensibly proceeds. Sometimes these are euphonic, e.g.. "moule poulpe pulpe vulve" (pp. 41-42) is rendered acceptably as "mussel sponge valve vulva" (p. 41). Sometimes these are lexical wordplays, e.g., when the Germans move in at the end: "Liessies comme liesse kermesse Hénin nennin Hirson hérisson hirsute Fourmies" (p. 309) is condensed to "Liessies Hénin Hirson Fourmies" (p. 315). Sometimes these are idioms with no counterpart, e.g., a straggler believed to be a "Frisé" (p. 229) is rendered "German" (p. 233) and his identifying characteristic "Tout rouquin qu' il était!" has to be explained "His hair was red!"

If forced to choose between a French nuance and normal English syntax, Howard remembers that he is creating an English novel. Take placing an adverb e.g., "il lui sembla qu'il le voyait réellement" (p. 79, literally "he thought he really saw him") becomes "he really thought he saw him" (p. 80). The continuous subtle narrator shifts, e.g. from "nous" to " $j e$ " to "Georges" to "on," etc., will be "we," "I," "Georges," "you," in the expectation that the English reader can distinguish between the indefinite "you" and the "you" of direct address. If the pronoun ambiguity, especially Simon's ubiquitous "le," becomes extraordinary, Simon will clarify, e.g., "Georges se demandant sans exactement se le demander" (p. 27) becomes "Georges wondering without exactly finding an answer" (p. 25).

Some of Howard's slight referential emendations, i.e., slightly altering the signifieds, might be termed restaging. E.g., during Georges and Blum's reconstruction of various probable scenes in the de Reixach's family history, there are slight emphasis changes: "Et Georges: "Mais non!" (p. 192) becomes "And Georges: "No that's'..." (p. 194); "Et Georges: 'Non.'” (p. 201) becomes "And Georges: 'No!'(p. 201). In peasant gossip "Il $n$ 'y a pas qu'une clef" (p. 269, literally "There isn't just one key") becomes "More than one key" (p. 274). Other referential emendations might be termed revisualizations. Georges thinks of his parents at their farm: "le marronnier en fleurs à cette époque, ses multiples grappes blanches comme des candélabres doucement phosphorescents dans le crépuscule" (p. 243) becomes "the chestnut tree in bloom then. Its white clusters like candelabras glowing softly in the twilight" (p. 248).

The problems that plague beginning translators, Howard, of course, solves leaving no trace of a struggle. "On" does not become "one." Infinitive constructions are activated, e.g., "Des discours D' enfiler des..." (p. 36) becomes "Of making speeches Of wasting your [Georges' father] time lecturing" (p. 35). Getting from grammatical gender to natural gender never bothers Howard who, as we have seen in our opening example " $s$ 'il $a$ capté" goes directly to the de facto agent and gives his allegiance to normal and neutral English. I suppose I would query translating "métayer, paysan," and "fermier," all as "farmer," but I can imagine Howard's reply: "métayer" is peculiarly French; "peasant" sounds pre-twentieth century to Americans; and although we have always been taught that "fermier" and "farmer" are not the same, in this case the latter is what is meant. ("Gentleman-farmer," incidentally, stays "Gentleman-farmer.") 
Howard maintains the motif words, e.g., virgin, virginal, Virginia (all from their cognates), or arrested motion words like fixed, frozen, immobile, suspended, and keeps them in Simon's pattern. He keeps Simon's often many-paged paragraphs.

A translator of Howard's talent and erudition will not miss literary and historical allusions, word-plays, untranslatable references. Furthermore, he resists giving American readers hints. Simon tells us who rode Bucephalos; so does Howard. Simon does not tell us who rode Rocinante; neither does Howard. He lets the reader figure out the relevance of Leda, the Atrides and do whatever background reading is needed on the Convention. English-language readers have as much help as French readers in sighting a scene in the manner of Boucher, Fragonard, La Tour, watching a Passacaglia, or remembering a transvestite murder mystery. The Atrides' re-enactment in rural wartime France introduces some black humor and word play. Simon's "petits boucs ... petits boiteux" (p. 129) becomes "little billygoats ... little limpers" (p. 128). Howard leaves a song in French:

$$
\begin{gathered}
\text { Granpèr! Granpèr! } \\
\text { Vouzou blié vo! tre! che! val! (p. 120/p. 119) }
\end{gathered}
$$

Perhaps even more impressive is the way Howard reproduces Simon's intentional eccentricities without preciousness and compensates where he has had to trim or restructure. He had one textual advantage: Simon's reliance on present participles is somewhat unusual in French, but when carried over into English simply results in a Faulknerian text. What must have been more taxing was Simon's use of broken sentences and halfenunciated words. Sometimes Howard finesses by putting complete words in an incomplete sentence. When in an example already quoted Georges tries to break up a deteriorating argument between Blum and Wack, the former says, "Laisse. Si tu savais comme je m'en f..." (p. 65). Howard has Blum say, "Forget it. If you knew how much you..." Georges discusses the latter's family keepsakes. Simon has the following: Blum is speaking, "Afin de perpétuer à l'usage de sa postérité, et en particulier alimenter la conversation de madame ta mère quand elle recev..., et Georges: Un peintre? Quel peintre? Je t'ai dit que le seul portrait qui existe de lui avait été bien avant que..." (p. 186). In Howard, we have "'In order to perpetuate for the use of his descendants, and in particular to supplement the conversation of your lady mother when she receiv...', and Georges: 'A painter? What painter? I told you the only picture that exists of him had been made long before..."' (p. 188). Howard's elevation of diction which we noted earlier accords with the English convention of moving toward formality to preserve intensity. Recall the episode right after de Reixach's death, the soldier who screams, "Foutez le camp de là! Foutez-vous en civil! Cherchez des fringues dans une maison et planquezvous!" (p. 110). Viewed from this perspective, Howard's choices appear to be compensatory: "Get out of those! Get into civilian clothes! Look for some clothes in a house and lie low!" (p. 109). It is almost a Shakespearean closure.

Indeed, poetic passages and formal closures have probably elicited Howard's finest translating. Howard, always sensitive to modulation in register, steps up a tone, as just cited, in order to be true to his sense of the appropriate overall effect. But he must have found Simon's epic voice especially congenial. In any event, he renders it superbly. The final paragraph of the novel returns to the scene of de Reixach brandishing his saber when struck by the sniper bullet. This time the narrator remembers or imagines he remembers seeing the sniper: "l'éclat du soleil sur l'acier noir à travers l'odorante et printanière haie d"aubépines" (p. 314. Howard says "the glint of sunlight on the black steel through the sweet-smelling hawthorne hedge," p. 320). The camera stops on this experience - making the film strip a still : 
le paysage tout entier inhabité vide sous le ciel immobile, le monde arrêté figé s'effritant se dépiautant s'écroulant peu à peu par morceaux comme une bâtisse abandonnée, inutilisable, livrée à l'incohérent, nonchalant, impersonnel et destructeur travail du temps (p. 314)

the whole landscape uninhabited under the motionless sky, the world stopped frozen crumbling collapsing gradually disintegrating in fragments like an abandoned building, unusable, left to the incoherent, casual, impersonal and destructive work of time (p. 320)

We have seen how attentive Howard has been to Simon's text throughout, reproducing it not without emendations but being true to his persuasive interpretation. So attentive, in fact, that we can recognize along The Flanders Road, as we can along la Route des Flandres, scenes from later novels - which he did not translate.

It is unlikely that Fletcher, Lane, and Weissbort would have pored over Howard's translations, although all are secure enough to do so. Chiefly responsible for Howard's clairvoyance, in my opinion, has been his deference to the text, not just to the text which we can examine, but the Ur-text which he largely had to intuit, what we have called his own sense of the text. I.e., he worked from the traditional narrative which Simon dislocated to produce a nouveau roman. With Simon, as with Faulkner, Joyce and Proust, the Urtext is always larger than the concretized text at hand. (Even a bricoleur may have a grand design behind his stopgap repair job.) Simon in English translation, for which Howard's la Route des Flandres is a stellar example, accurately and sensitively recreates Simon in French. The elusive, carefully dislocated patterns are just as resilient and pictorial in one language as in the other.

Yet Simon's oeuvre has had a cerebral and tepid response with English readers. To return to the other side of our question, if the translations are not to blame, what is? Why has his work had so little impact? After all, Faulkner, also out of print on the eve of his Nobel award in 1949, has grim, even sordid, material often with no less apparent authorial complicity than Simon, in a style that also requires patience. Still, I think Faulkner suggests a tentative, if simplistic, answer. For all the crime and stupidity interwoven in the saga of Yoknapatawpha County, there are enough decent people in positions of responsibility in that legendary segment of the Mississippi Mid-World for the races, classes, and sexes who live there to endure and prevail. As a collectivity Yoknapatawpha County has come through tragic experiences which it in large measure brought on itself and transcended them. In the final analysis, Faulkner - like Homer, Dante, Shakespeare, Goethe, and in my opinion, Camus as well - has affirmative as well as negative implications. Restricting examples only to Nobel laureates, I think it could be claimed that Gide, Mauriac, even Beckett, always make it clear by implication first what the decent or forthright course of action would be and second that their sympathies lie with that course of action. With Simon such sympathy is at best elusive. The cliché that truly great literature must be in some measure affirmative would seem to be validated here. The Nobel Academy, required to honor writers with an uplifting message, had to word the award text very carefully: "quelque chose qui vit en nous, que nous le voulions ou non, que nous le comprenions ou non, que nous le croyions ou non" ("something within us all, whether or not we wish it, understand it, or believe it"). ${ }^{17}$ His translators in being true to him as they read him can only perpetuate the complex of qualities which limit his appeal, and, probably, posterity. The Nobel prize is unlikely to gain him many more readers. His world is confusing and cluttered. Amidst the corpses of horses and men on the Flanders Road, a reader must struggle to make headway.

But those who discover him now in English translation have a reliable entry. 
Notes

1. The award in 1985 was both political and apolitical. Most obviously it was apolitical. Accordingly to Le Monde, October 19, 1985, the Swedish academy had chosen to be punitively oblivious of French writing ever since Sartre refused the award in 1964. Further, Le Monde claimed that there were rumors that a country which sank "The Rainbow Warrior" did not deserve recognition for nobility in letters. Thus, if Simon was elected anyway, that fact could indicate that the Academy could rise above political considerations. Nevertheless, that choice, i.e., to be apolitical, is, in itself, political, for it implies that literary criteria should be foremost.

Whatever the Academy's reasons for selecting this reportedly often-nominated Nouveau romancier, the announcement caused little excitement and less coverage. The decision was announced by the Nobel Academy, October 16, 1985. The French press apparently had prior warning, so that it could print the news, October 17. It took until the 19th, however, for full- feature treatment; the French, I noticed, gave the death of Orson Wells far more space. In my mini-major press survey, I found that generally the story ran on October 18 for both the U.S. and West European newspapers. Corriere della Sera ran a full page in the arts section even in the midst of the "Achille Lauro" turmoil. El País gave a full page, helpfully listing the Spanish translations and whether or not they were obtainable in Madrid. The Neue Züricher Zeitung, which ran the announcement on October 16, devoted a feature story in the feuilleton section, October 18. U.S. newspapers generally stayed with 500 -word releases. Both the New York Times (Steve Lohr, October 18, 1985 ) and Time (Paul Gray, October 28, 1985, p. 88) gave the scanty coverage for a Nobel award : both were moderately disparaging, unlikely to spark readers' curiosity. As far as another colleague and I could tell, the Frankfurter Allgemeine Zeitung decided not to notice the award at all.

2. Stuart Gilbert's over-interpretative translation has been criticized repeatedly, and only a self-translator like Beckett could get by with so many cultural substitutions.

3. Hans Ulrich Gumbrecht, "Canon to Classic," trans. Roger C. Norton, New Literary History, forthcoming. I am grateful to my colleague Norton for letting me read his translation in manuscript.

4. Ever since the nouveau roman first came upon the scene with Nathalie Sarraute's Portrait d'un homme inconnu in 1947, scholars have taken note of Simon. There are always a few entries in the $M L A$ bibliography, and from time to time papers at professional meetings. Over a decade ago he achieved the distinction of eliciting a Cerisy colloquium (Jean Ricardou et al., Claude Simon : Colloque à Cerisy [Paris : 10/18, 1975]), and Critique (Paris) gave him a monograph issue in 1981. For my preliminary investigation of Simon's English translations for the 1984 Northeast MLA meeting, Philadelphia, March 29, 1984, I wrote to him and to all his translators; after the Nobel award I got back in touch. Not only have the criticism camps found his texts a fertile terrain for defoliation and landmining, but such transcendent luminaries as Merleau-Ponty, Barthes, and Lévi-Strauss have paid attention to him.

5. John W. J. Fletcher (1937-), The Georgics (in progress), is professor of Comparative Literature in the School of Modern Languages and European History, University of East Anglia. He is best known for his work on Samuel Beckett. He writes, November 17, 1985, that he is aiming for "mid-1986."

Helen Ruth Lane (Minneapolis native living in France), Conducting Bodies (Calder / Riverrun, 1980), Triptych (Viking, 1976), taught at UCLA, Goucher, and New York University. She received the 1973 P.E.N. Translation Prize for Count Julian by Goytisolo and the 1979 Gulbenkian Foundation Translation Prize for The Three Marias : New Portuguese Letters by Barreno, Horta, Velhoda Costa.

Richard Howard (Cleveland, Ohio, 1929-) received the Pulitzer Prize for Poetry in 1970. He has translated Histoire, The Wind, The Grass, The Battle of Pharsalas, and The Palace also. His publisher is Jonathan Cape / George Braziller. He has translated Arrabal, Barthes, Baudelaire, Breton, Butor, Camus, Cocteau, Genet, Gide, Leiris, Robbe-Grillet, and Todorov.

Daniel Weissbort (1935-), The World About Us (Ontario Review Press, 1983), albeit London-born, directs the translation program of the Creative Writing Program at Iowa University where he is professor of Comparative Literature.

6. This guidance comes not from direct collaboration. As a matter of fact, Simon, who commends his English translations, also disparages his own command of English (letter to author, 11 December, 1983). Rather, the guidance comes from the imposing structure and lexicon which leave the translator little leeway. Weissbort, for example, says Simon "dictates" the translation (letter to author, November 26, 1983).

7. Tony Cartano (1985) : "Le plus "sud-américain' de nos écrivains," Le Monde hebdomadaire, October, $17-23$.

8. Letter to author, December 11, 1983. Fletcher, Howard, and Weissbort indicate that Simon is very helpful Fletcher, discussing the lexicon in Georgics, says sometimes the language is so very colloquial that even slang dictionaries do not give the English sense, at other times it is so technical that Simon, who may have copied the passage from his ancestor's papers will not know what it means. Fletcher's problems with Georgics suggest that translation difficulties, not surprisingly, increase in proportion to stylistic density. He compares translating the multiple-clause sentences to stuffing a lot of socks into a slippery plastic bag (letter to author, February 2, 1984). 
9. Paris, Éditions de Minuit, 1973, p. 209 ; New York, Viking, 1976, p. 159.

10. These writers, whom Simon admires and resembles have nonetheless different intertextual strategies. Faulkner's Yoknapatawpha Saga has more accessible references (at least for American readers) and a broader, less overlapping spectrum. Joyce's Dublin is actually small, even though enlarged by history and literature. Proust's Paris-Combray-Balbec-Venice nexus is within a single work. Furthermore, the subject, i.e., the knower, the narrative point-of-view, can be identified as a point of reference. (To anticipate, they are clearly pro-human and leave a reader basically encouraged by human survival.) For an excellent summation of Simon, see John Fletcher, "Claude Simon: autobiographie et fiction," Critique, $\mathrm{n}^{\circ} 414$ (novembre 1981): pp. 1211-1217. Fletcher maintains that the first novels le Tricheur (1946), la Corde raide (1947), and Gulliver (1952) show Simon's absorption of his "maîtres" Conrad. Faulkner, and Proust. They also introduce most of Simon's repertory of obsessive direct personal experiences. La Corde raide introduces de Reixach's last cavalry march during the French defeat in 1939-1940 and (Simon's preferred persons) Georges' recollections of being on a train to a stalag. The vignettes in these novels are fairly clear as vignettes. Gulliver shows the demoralization on a micro-level in a community not directly affected by World War II. Le Sacre du printemps (1954), my favorite novel, shows the late adolescent psychology of students in the early 1950's. From the standpoint of Simon's corpus it is important for introducing Simon's experiences as a volunteer on the Republican side of the Spanish Civil War. With le Vent (1957), no more Faulknerian in its style than le Sacre du printemps, but far more analogous to Faulknerian content, Simon settles into his Jura and Limoges setting and takes up, I think, an unsuccessful attempt of a returning native to reclaim his estate. L'Herbe (1958) picks up Georges' family through about four hours of his wife's consciousness. She will leave him as soon as his aunt's death agony comes to a close. La Route des Flandres (1960) gives us the de Reixach family and its retainers and cousins, the cast of characters that we could have used earlier, and will need for the rest of Simon's corpus. This novel is surely one of the best novelistic means we have for living through collapse of the French armed forces by a novelist who experienced the frustration, shame, and physical hardship. Le Palace (1962) returns to Spain, an urban setting that mingles features of Barcelona and Madrid, when a general is assassinated and his funeral held. Once again, only a few hours of narrative time elapse; during this time, however, the American volunteers realize that it is time to leave and do so. Histoire (1967) moves back into the de Reixach milieu and to the extent the narrative has any moving forces is impelled by an immense postcard collection which the "je" is thumbing through. La Bataille de Pharsale (1969) adds the site of Julius Cesar's defeat of Pompeii, 47 B.C. to Simon's personal memory pool and integrates it with Corinne, Madame de Reixach, then a little girl, who receives some of those postcards of Histoire. Epigraphs from Valéry, Proust and Heidegger divide the novel into three parts. Les Corps conducteurs (1971) is purely associational, beginning with plastic legs in a hosiery shop. although there are some moments of irony recording some writers' congresses Simon attended. Triptyque (1973) is a collage of media sex and revolting sex acts in a seedy rural resort setting; Lambert, who passed through Histoire, is mentioned as if a film star. La Leçon de choses (1975) intersperses scenes from either World War I or II, once again a cavalry rout, with sexual abuse and incomplete newspaper headlines which are a CLOZE test for the dramatis personae of la Route des Flandres. Les Georgiques (1981) brings together all the important obsessive events in Simon's history, adding now the role his family had in the Convention period in Simon's history, adding now the role his family had in the Convention period (1792-1795). The props and family tree are Simon's own, and perhaps the universality of the experience Ike McCaslin has in "The Bear" is borne out. I.e., any family that stays in one place long enough to have a sense of its own history as well as that of its region, will have both a material and spiritual legacy with which the heirs must or should come to terms. "Uncle Charles," the revolting rapist in Leçon de choses, passes on the letters - and the moral - to " $t u$ " : "Quand tu seras vieux toi-même. Je veux dire quand tu seras capable non pas de comprendre mais de sentir certaines choses parce que tu les auras toimême éprouvées..." (p. 445, "When you're old yourself. I mean when you will be capable not of understanding but of feeing certain things because you will have experienced them yourself"). Finally la Chevelure de Bérénice (1983, but written in 1965) is basically a multi-stanza prose poem about three Mediterranean women on the beach ; since there are soldiers about, I assume it is the Spanish coast. It may be that this pamphlet was published just to help the Nobel nomination.

11. Saber suicide, argument with parents, ancestor's discovery of infidelity, rural incest, dying horse, rotted horse, Iglésia and Corinne in stable, Iglésia-de Reixach-Corinne at steeplechase, Georges' meeting with Corinne after the war, stalag, POW deportation, cavalry general's suicide.

12. Note to author, November $18,1983$.

13. Editions used: Paris, Éditions de Minuit, 1960; New York, George Braziller, 1961.

14. See David Carroll (1982): The Subject in Question, University of Chicago; Doris Kadish (1979): Practices of the New Novel in Claude Simon's l'Herbe and la Route des Flandres, York, Canada. These two recent additions to the slight but steady flow of Simon criticism are valuable in tandem : Carroll shows the complexity within simplicity, and Kadish shows the simplicity within complexity. She either caught far more plot and narrative lines than Carroll or records more of them. Carroll (p. 132) astutely observes that this 
novel originates from the space Georges occupies, not from him. There is nothing random about the arrangement; after all, Simon confessed to writing this novel with a different colored pencil per character to keep their lines straight (André Bourin, "Technicien du roman : Claude Simon," les Nouvelles littéraires [29 décembre 1960], quoted in Robert L. Sims, "Claude Simon's Bricolage Technique in la Route des Flandres, le Palace and Histoire," Degré second, ${ }^{\circ} 7$ (July, 1983), p. 85.

15. The English typography is much more legible : 32 46-character leaded lines per page vs the French 3157 character (nearly) unleaded lines per page.

16. "A conversation with William Weaver," Translation Perspectives III 1985-86, Ed. M. G. Rose, SUNYBinghamton, forthcoming).

17. Le Monde hebdomadaire, 17-23 octobre 1985

\section{BIBLIOGRAPHY}

BURDEN, Robert (1980) : John Fowles, John Hawkes, Claude Simon, Würtsburg, Königshauser and Neumann. CARROLL, David (1982) : The Subject in Question, Chicago, University of Chicago Press.

FLETCHER, John (1981): "Claude Simon : autobiographie et fiction," Critique, $\mathrm{n}^{\circ} 414$ (novembre), pp. $1211-$ 1217.

GUMBRECHT, Hans Ulrich (forthcoming) : "Canon to Classic," trans. Roger C. Norton, New Literary History.

KADISH, Doris (1979): Practices of the New Novel in Claude Simon's l'Herbe and la Route des Flandres, York, Ontario, York Press.

Popular Press: Corriere della Sera, October 18, 1985; Neue Züricher Zeitung, October 16, 1985; New York Times, October 18, 1985; le Monde, hebdomadaire, October 16-23, 1985 and November 13, 1985 ; El País, October 18, $1985 ;$ Time, October 28, 1985

RICARDOU, Jean et al., Claude Simon (1975): Colloque à Cerisy, Paris, 10/18.

SIMON, Claude (1947) : la Corde raide, Paris, Éditions du Sagittaire.

SIMON, Claude (1952) : Gulliver, Paris, Calmann-Lévy.

SIMON, Claude (1954): le Sacre du printemps, Paris, Calmann-Lévy.

SIMON, Claude (1957) : le Vent, Paris, Éditions de Minuit. Trans. Richard Howard (1959): The Wind, New York, George Braziller.

SIMON, Claude (1962) : le Palace, Paris, Éditions de Minuit. Trans. Richard Howard (1963): The Palace, New York, George Braziller.

SIMON, Claude (1958): l'Herbe, Paris, Éditions de Minuit. Trans. Richard Howard (1958): The Grass, New York, George Braziller.

SIMON, Claude (1967): Histoire, Paris, Éditions de Minuit. Trans. Richard Howard (1967): Histoire, New York, George Braziller.

SIMON, Claude (1969): la Bataille de Pharsale, Paris, Éditions de Minuit. Trans. Richard Howard (1971): The Battle of Pharsalus, New York, George Braziller.

SIMON, Claude (1971): les Corps conducteurs, Paris, Éditions de Minuit. Trans. Helen R. Lane (1980): Conducting Bodies, Riverrun, NY, Riverrun Press.

SIMON, Claude (1973) : Triptyque, Paris, Éditions de Minuit. Trans. Helen R. Lane (1976): Triptych, New York, Viking.

SIMON, Claude (1975): Leçon de choses, Paris, Éditions de Minuit. Trans. Daniel Weissbort (1983): The World About Us, Princeton, NJ, Ontario Review Press.

SIMON, Claude (1981): les Géorgiques, Paris, Éditions de Minuit. Trans. John Fletcher (forthcoming): Georgics, Riverrun, NY, Riverrun Press.

SIMON, Claude (1965) : la Chevelure de Bérénice. Paris, Éditions de Minuit, 1983. 